\title{
Seasonal Dynamics of Phloem and Xylem Formation in Silver Fir and Norway Spruce as Affected by Drought ${ }^{1}$
}

\author{
J. Gričar ${ }^{a}$ and K. Čufar ${ }^{b}$ \\ ${ }^{a}$ Slovenian Forestry Institute, Večna pot 2, SI-1000 Ljubljana, Slovenia; \\ fax: + 386-1-257-3589; e-mail: jozica.gricar@gozdis.si \\ ${ }^{b}$ University of Ljubljana, Biotechnical Faculty, Department of Wood Science and Technology, Rožna dolina, \\ Cesta VIII/34, SI-1000 Ljubljana, Slovenia
}

Received December 19, 2006

\begin{abstract}
The dynamics of phloem growth ring formation in silver fir (Abies alba Mill.) and Norway spruce (Picea abies Karst.) at different sites in Slovenia during the droughty growing season of 2003 was studied. We also determined the timing of cambial activity, xylem and phloem formation, and counted the number of cells in the completed phloem and xylem growth rings. Light microscopy of cross-sections revealed that cambial activity started on the phloem and xylem side simultaneously at all three plots. However, prior to this, 1-2 layers of phloem derivatives near the cambium were differentiated without previous divisions. The structure of the early phloem was similar in silver fir and Norway spruce. Differences in the number of late phloem cells were found among sites. Phloem growth rings were the widest in Norway spruce growing at the lowland site. In all investigated trees, the cambium produced 5-12 times more xylem cells than phloem ones. In addition, the variability in the number of cells in the 2003 growth ring around the stem circumference of the same tree and among different trees was higher on the xylem side than on the phloem side. Phloem formation is presumably less dependent on environmental factors but is more internally driven than xylem formation.
\end{abstract}

Key words: Picea abies - Abies alba - phloem - sieve cells - cambial activity - xylem - cell differentiation - light microscopy

DOI: $10.1134 / \mathrm{S} 102144370804016 \mathrm{X}$

\section{INTRODUCTION}

In trees, the addition of new cells to secondary xylem and secondary phloem increases the stem diameter. It is accomplished by periclinal cell divisions in the vascular cambium. During the differentiation, the cells develop their final size, their specialized structure and function. Divisional activity of the cambium is normally more intense on the xylem than on the phloem side. Consequently, xylem in a tree stem accumulates faster than phloem. However, the ratio between xylem and phloem becomes progressively smaller when the tree grows under unfavorable conditions [1-4].

Many investigations have recently dealt with the seasonal dynamics of cambial activity and wood formation in various tree species (e.g. [5-11]). However, studies on phloem formation during the vegetation period are still scarce [2, 12-15], very likely because of the greater commercial importance of xylem than of phloem. Since phloem collapses within a few years after its formation, cellular structure can be studied only in a narrow zone close to the cambium, the socalled conducting zone. The older tissues of bark are

\footnotetext{
${ }^{1}$ This text was submitted by the authors in English.
}

usually crushed and, eventually, the external, distorted and collapsed phloem tissues are sloughed off. It is therefore difficult to distinguish older phloem growth rings or determine the year of their formation. For all these reasons, phloem is rather unsuitable for dendrochronological or dendroecological studies.

The purpose of this research was to study the structure of phloem growth rings in silver fir (Abies alba) and Norway spruce (Picea abies), as well as the dynamics of phloem growth ring formation in the vegetation period of 2003 at three sites in Slovenia. In addition, we compared the timing of cambial divisional activity, xylem and phloem formation, and the number of cells in the completed phloem and xylem annual growth rings.

\section{MATERIALS AND METHODS}

Silver fir (Abies alba Mill.) trees were selected in a permanently monitored typical silver fir/beech forest stand located at Ravnik/Slovenia (elevation 500-700 m), about $50 \mathrm{~km}$ southwest of Ljubljana $\left(46^{\circ} \mathrm{N}, 14^{\circ} \mathrm{E}\right)$, in the Dinaric region. The selected trees were 150 180 years old and had a mean stem diameter at breast height of approx. $50 \mathrm{~cm}$. 
The investigations in Norway spruce (Picea abies (L.) Karst.) were performed on dominant and co-dominant trees growing at Sorsko polje (350 $\mathrm{m}$ a.s.l.) and Pokljuka (1200 m a.s.l.). The Sorsko polje site, approximately $30 \mathrm{~km}$ northwest of Ljubljana, is a typical lowland plantation of Norway spruce, growing on shallow soils of detritus of the Sava River. The Pokljuka site about $60 \mathrm{~km}$ northwest of Ljubljana, is a typical, natural, sustainably managed sub-alpine spruce forest (Piceetum subalpinum) characterized by low winter temperatures and high amounts of snow. We selected trees of about 70 years of age with similar biometric characteristics. Their mean diameter at breast height was around $30 \mathrm{~cm}$ at Sorsko polje and $37 \mathrm{~cm}$ at Pokljuka.

At each site, we selected 4 apparently healthy trees and carried out sampling at weekly intervals from April until November 2003. Samples containing inner phloem, cambium, and outer xylem $\left(30 \times 10 \times 10 \mathrm{~mm}^{3}\right)$ were taken at breast height (1.3 $\mathrm{m}$ above ground) around the entire stem circumference. The distance between neighboring samples was at least $10 \mathrm{~cm}$ in a horizontal direction to avoid the effect of wounding. After sampling, blocks of tissue were immediately immersed in FAA (formaldehyde-ethanol-acetic acid) and dehydrated after one week using a graded ethanol series $(30,50$, and $70 \%)$. Transverse sections $(20 \mu \mathrm{m}$ thick) for light microscopy were prepared without further processing, using a LEICA SM 2000R sliding microtome. They were double-stained with safranin and astra blue. Sections were permanently mounted on glass slides using Euparal. A Nikon Eclipse 800E light microscope (bright field, polarized light) and LUCIA G 4.8 image analysis system were used for anatomical observations and analysis. Radially flattened cells of dormant cambium with thin primary walls could be easily distinguished from differentiated secondary phloem. An increase in the number of cells in the cambium indicated its divisional activity. Expanding cells, with thin primary walls between the cambium and the secondary phloem cells with thicker secondary walls, were considered to be sieve cells in the stage of post-cambial growth. The initiation of the secondary wall thickening was determined by birefringence in the cell walls under polarized light. In cross-section, the number of cells in the current xylem and phloem growth rings were counted along three radial files of cells and averaged.

\section{RESULTS}

\section{Anatomical Structure of Bark in Abies alba and Picea abies}

Bark is structurally more complex than wood and includes all tissues outside the vascular cambium [1622]. More specifically, bark tissues consist of noncollapsed and collapsed secondary phloem, cortex, and periderm. Secondary phloem includes all bark tissues derived from the vascular cambium during secondary growth [22]. It is composed of accumulated layers of annual growth rings. The structure of conducting phloem of Abies alba and Picea abies is relatively simple and consists of living, vertically oriented mature sieve cells and various types of parenchyma cells, which can include crystals, tannins, resins, lipids, etc. (Figs. 1a, 1b). Within the gymnosperms, only the Pinaceae have an additional wall layer, which is considered as secondary wall by Abbe and Crafts [16]. Secondary cell walls of sieve cells are unlignified, which is characteristic of Pinaceae. The ray system in Abies alba involves uniseriate rays and in Picea abies uniseriate and fusiform rays. Phloem parenchyma bands separating early phloem from late phloem sieve cells are arranged in more or less tangential bands (usually one or two cells thick) and are conspicuous by dark stained contents in the cell lumina. These bands do not represent annual growth ring boundaries, although they may appear to do so. A second, but discontinuous tangential band of parenchyma cells sometimes forms in the late phloem at the end of the growing season. This is typical of wider phloem growth rings (Fig. 1b). Characteristics of phloem parenchyma cells and the dimensions of the sieve cells help us to identify annual phloem growth rings, as well as early and late phloem. Early phloem sieve cells generally have wider radial dimensions and thinner cell walls compared to late phloem sieve cells. The tangential walls of the first sieve cells of the early phloem adjacent to the previous year's crushed sieve cells are slightly rounded up (Fig. 1b). The youngest phloem growth ring is thus located between the cambial cells and the previous year's often already crushed sieve cells. The cessation of the conducting function of the sieve cells is accompanied by accumulation of callose on sieve plates, followed by the loss of cell contents and collapsing of the cell. As a result of the collapse and obliteration of sieve cells, the enlargement of parenchyma cells, formation of sclereids, and distortion of rays in the outermost noncollapsed phloem, the older phloem growth rings become more and more indistinguishable with increasing distance from the cambium.

\section{Dynamics of the Phloem Growth Ring Formation}

In Norway spruce at the sub-alpine site Pokljuka, the differentiation of the first early phloem sieve cells started before the onset of the divisions in the cambium in mid-May (Fig. 2). The outer 1-2 layers of undifferentiated cambial cells expanded radially and is differentiated without previous divisions, when the cambium was still dormant and was composed of 6 to 7 layers of cells. The first solitary parenchyma cells were laid down by the end of May. They were well visible by their dark stained contents. This band is arbitrarily used to delineate early phloem from late phloem sieve cells in a given season's growth increment. In most trees, differentiation of early phloem consisting of 4-5 layers of sieve cells was completed by the end of June. The initial early phloem sieve cells had larger radial dimensions 
(a)

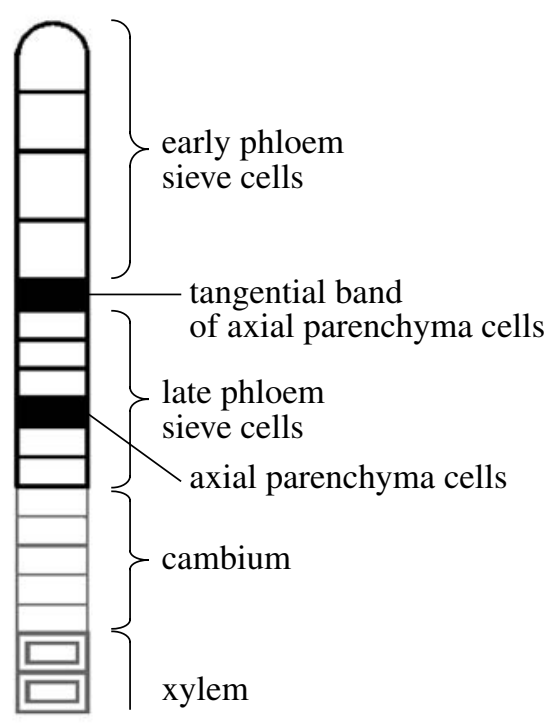

(c)

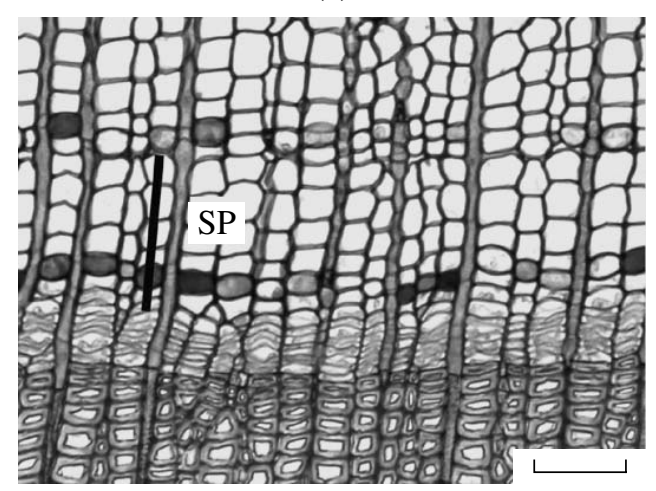

(b)

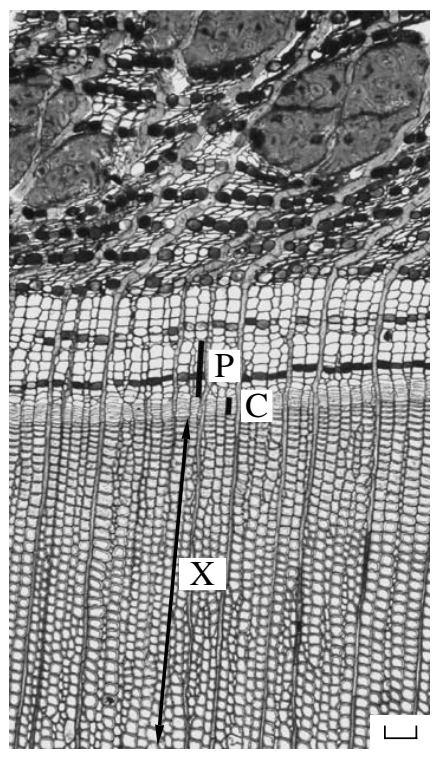

(d)

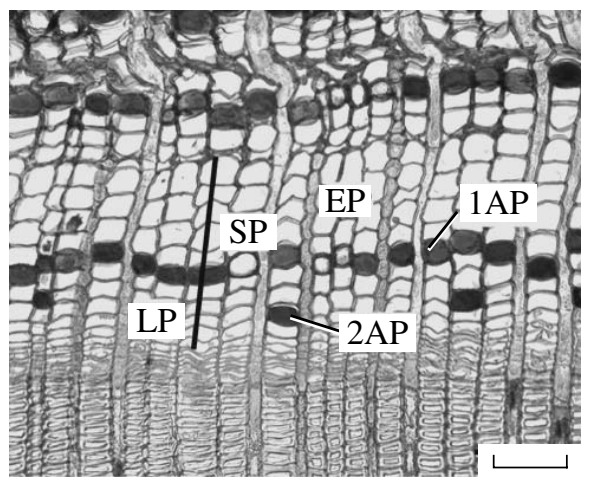

Fig. 1. (a) Schematic illustration of the latest formed annual phloem growth ring in silver fir or Norway spruce; (b) light micrograph of the secondary phloem in silver fir; (c) light micrograph of the youngest secondary phloem growth ring in silver fir; (d) light micrograph of the wider phloem growth ring in Norway spruce containing a second, discontinuous band of axial parenchyma cells in the late phloem.

$\mathrm{P}$ - the youngest annual phloem growth ring, $\mathrm{C}$ - cambium, $\mathrm{X}$ - part of the youngest annual xylem growth ring; $\mathrm{SP}-\mathrm{secondary}$ phloem growth ring; EP - early phloem sieve cells, LP-late phloem sieve cells, $1 \mathrm{AP}$ - first band of axial parenchyma, $2 \mathrm{AP}-\mathrm{sec}-$ ond band of axial parenchyma. Scale bars $=100 \mu \mathrm{m}$.

than those formed last. Development of early phloem was succeeded by the formation and differentiation of late phloem sieve cells with smaller radial dimensions. The maturation of late phloem continued at a fairly steady rate into mid-September (Fig. 2). At the end of the vegetation period in autumn, late phloem numbered up to 4 layers of cells.

At the lowland site Sorsko polje, the dormant cambium of Norway spruce consisted of 6 to 7 layers of radially flattened cambial cells arranged in radial files. However, at the end of the April, cambial divisions had already started, as concluded from the increased number of cambial cells, up to 14 layers. Prior to cambial reactivation, 1-2 layers of cambial cells on the phloem side expanded. The formation of new sieve cells began in the first week of May (Fig. 2). By mid-May, early phloem was already formed, consisting of up to 4 layers of sieve cells, of which the first 2 layers had already maturated. By that time, the tangential band of phloem parenchyma had started to form. The differentiation of early phloem was completed by the beginning of June, followed by late phloem formation. At the end of July, divisions in the cambium ceased. Late phloem was composed of 4-6, rarely 7 layers of sieve cells. The latest formed cells were fully developed by mid-August (Fig. 2). Only in a few cases, a second band of parenchyma cells was observed in the late phloem. 
In silver fir at Ravnik, the activation of the cambium occurred at the end of April, when the number of cells in the cambium doubled from 7 to 14 cell layers (Fig. 2). At that time, 1-2 layers of early wood sieve cells were already in the process of differentiation. By the beginning of May, the first phloem parenchyma cells were detected. In mid-June, the early phloem was composed of up to 4 fully differentiated sieve cells. The formation and differentiation of late phloem sieve cells occurred in the second half of June, in July, and in August. Cambial divisions stopped at the end of August, when 23 layers of late phloem sieve cells in total were formed. The latest formed phloem cells were fully developed by mid-September (Fig. 2). We did not detect a second band of axial parenchyma cells in any of the examined slides.

\section{Xylem and Phloem Growth Rings}

The timing of xylem and phloem formation differed among the sampling sites. Phloem differentiation in all study trees preceded both; divisions in the cambium and the formation of xylem. However, cambial activity of the investigated trees first started in silver fir (Ravnik) and Norway spruce at the lowland site (Sorsko polje), i.e., at the end of April (Fig. 2, Table 1). Divisions in the cambium occurred simultaneously on the xylem and phloem sides. Cambial divisions ended in Norway spruce at the lowland site at the end of July, in Norway spruce at the sub-alpine site (Pokljuka) in mid-August, and in silver fir at the end of August. At all three plots, xylem formation (secondary wall formation and lignification) in the terminal late wood tracheids continued for about 7-9 weeks after the termination of cambial activity. To summarize, cambial activity and corresponding wood formation were the longest in silver fir and the shortest in Norway spruce at the lowland site (Fig. 2, Table 1). Similarly to xylem formation, the development of phloem cells began first in silver fir and Norway spruce at the lowland site (Fig. 2, Table 1). The latest formed sieve cells were fully developed at first in Norway spruce at the lowland site (end of August) and last in silver fir (end of September). This occurred in all trees approximately 4 weeks after the cessation of the cell divisions in the cambium.

At the end of the growing season 2003, the phloem increment contained 6-9 cell layers in silver fir, 8-13 layers in Norway spruce at the lowland site, and 7-11 layers of cells in Norway spruce from the sub-alpine site (Table 2). The xylem growth rings 2003 were the widest in silver fir (50-95 cell layers) and the narrowest in Norway spruce at the lowland site (29-36 cell layers); the xylem growth rings in Norway spruce at the sub-alpine site were generally 37-46 layers of cells wide (Table 2). The cambium generally produced 5 to 12 times more xylem than phloem cells. Thus, the variability in the number of cells in the growth rings 2003 around the stem circumference of the same tree and

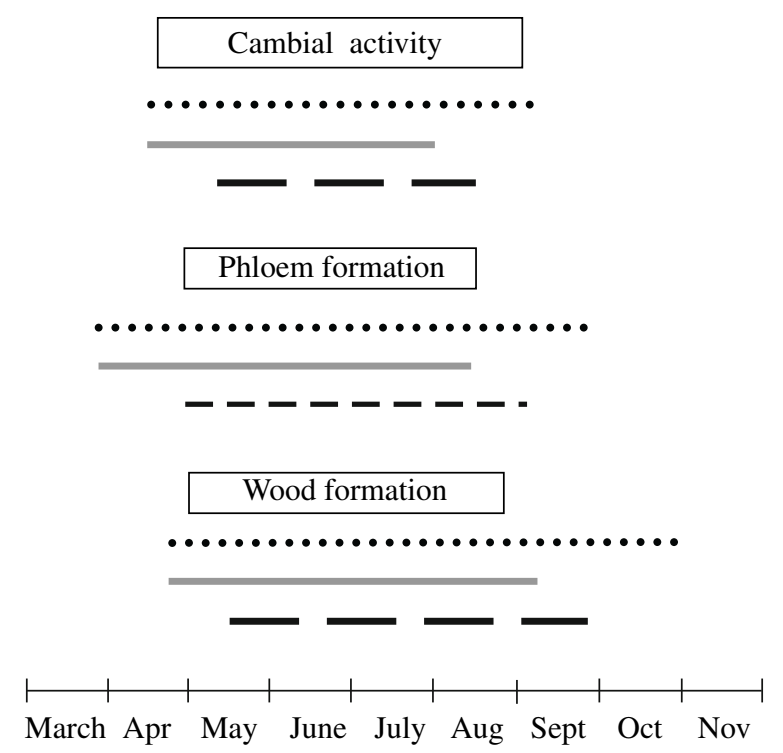

Fig. 2. Timing of cambial activity and phloem and wood formation in silver fir at Ravnik (dotted line) and Norway spruce at Sorsko polje (solid line) and Pokljuka (dashed line) in 2003.

among different trees from the same sampling site was larger on the xylem than on the phloem side.

\section{DISCUSSION AND CONCLUSIONS}

The structure of early phloem was similar in Norway spruce and silver fir, at all three sites. It was composed of sieve elements characteristic of Pinaceae. In all trees, the early phloem was composed of 3-4 layers of sieve cells, with wide radial dimensions and thin walls.

In both tree species, the cambium started to produce new phloem and xylem cells simultaneously, which is in contrast to observations of Antonova and Stasova

Table 1. Duration of cambial activity and phloem and xylem formation in silver fir at Ravnik and Norway spruce at the lowland site Sorsko polje and the subalpine site Pokljuka, weeks

\begin{tabular}{l|c|c|c}
\hline \multirow{2}{*}{ Process } & \multicolumn{3}{|c}{ Species (plot) } \\
\cline { 2 - 4 } & $\begin{array}{c}\text { Silver fir } \\
\text { (Ravnik) }\end{array}$ & $\begin{array}{c}\text { Norway } \\
\text { spruce } \\
\text { (Sorsko polje) }\end{array}$ & $\begin{array}{c}\text { Norway } \\
\text { spruce } \\
\text { (Pokljuka) }\end{array}$ \\
\hline $\begin{array}{l}\text { Cambial } \\
\text { activity }\end{array}$ & 19 & 14 & 15 \\
$\begin{array}{l}\text { Phloem } \\
\text { formation } \\
\begin{array}{l}\text { Wood } \\
\text { formation }\end{array}\end{array}$ & 26 & 21 & 22 \\
\hline
\end{tabular}

No. 42008 
Table 2. The number of cells in the xylem and phloem growth rings in 2003 and the structure of the phloem increments in silver fir and Norway spruce at different sites

\begin{tabular}{l|c|c|c}
\hline \multirow{2}{*}{ Tissue } & \multicolumn{3}{|c}{ Species (plot) } \\
\cline { 2 - 4 } & $\begin{array}{c}\text { Silver fir } \\
\text { (Ravnik) }\end{array}$ & $\begin{array}{c}\text { Norway } \\
\text { spruce } \\
\text { (Sorsko polje) }\end{array}$ & $\begin{array}{c}\text { Norway } \\
\text { spruce } \\
\text { (Pokljuka) }\end{array}$ \\
\hline Xylem ring & $50-95$ & $29-36$ & $37-46$ \\
Phloem ring & $6-9$ & $8-13$ & $7-11$ \\
& $\begin{array}{l}\text { (EP 3-5; } \\
\text { LP 2-3; } \\
\text { AP 1-2) }\end{array}$ & $\begin{array}{c}\text { LP 4-7; } \\
\text { AP 1-2) }\end{array}$ & $\begin{array}{c}\text { LP 3-5; } \\
\text { AP 1-2) }\end{array}$ \\
\hline
\end{tabular}

Notes: EP — early phloem, LP_late phloem, AP — tangential band of axial parenchyma.

[15] in Scots pine in Siberia. Prior to the cambial activity, the differentiation of 1-2 layers of phloem derivatives occurred without previous divisions, which is in agreement with earlier investigations in Pinus sp., Picea mariana, Abies balsamea, and Larix laricina $[2,12,13,23]$. According to these authors, sieve cells of the secondary phloem function only for a short period, usually one season, and the latest formed sieve cells that overwinter in a mature state are the first functional sieve cells in the next spring. In Pinus sp., Picea mariana, Abies balsamea, and Larix laricina phloem differentiation could occur for more than a month earlier than xylem differentiation $[12,13]$. The arrangement of phloem parenchyma cells delineated early and late phloem. Approximately two weeks after cambial activation, a tangential band of axial parenchyma cells started to form, irrespective of tree species and growth site. So, the period of formation and differentiation of the early phloem was shorter than of the late phloem. The differentiation of the latest formed sieve cells, however, continued for about four weeks after the cessation of cambial activity. The development of terminal late wood tracheids as well continued for about 79 weeks after the cessation of cambial activity $[24,25]$.

Fewer late phloem cells were formed in silver fir from Ravnik compared to the Norway spruce at the sub-alpine site (Pokljuka) and the lowland site (Sorsko polje), although cambial activity was approximately 4-8 weeks longer. This could indicate differences between tree species or differences in age. The silver fir trees were more than 80 years older than the Norway spruce trees, and their cambial productivity in terms of phloem formation might be reduced due to age. The widths of the phloem growth rings were reported to be wider and structurally different in younger silver firs than in older ones [14]. In addition, more layers of late phloem cells were observed in Norway spruce at the lowland than at the sub-alpine site, while the length of the period for its production was similar.
In all sampled trees in 2003, more xylem than phloem cells were produced, indicating more intense cell divisions on the xylem side, which is typical for trees growing under favorable conditions [1-4]. As a result, the increments were wider in the xylem than in the phloem, but the growth ring width varied around the stem circumference much more in the xylem than in the phloem. Xylem growth rings in 2003 were the narrowest in trees at the lowland site. This site is droughty, and the amount of precipitation possibly affects the duration and especially the termination of the vegetation period in terms of cell production. Since the summer of 2003 was abnormally warm and dry all over the Europe [26], the spruce at the lowland site experienced a pronounced drought stress. In summer 2003, only about $55 \mathrm{~mm}$ precipitation per month was recorded at the lowland site and about $150 \mathrm{~mm}$ per month at the subalpine site. This was the most possible cause that the cambial activity in Norway spruce from the lowland site stopped nearly one month earlier in 2003 than in 2002 and 2004 [25]. As a result of the shorter duration of cambial activity, the xylem increments in 2003 were narrower than in 2002 and 2004. In contrast, the increment of the phloem, particularly that of the late phloem, stayed unaltered.

The study of experimentally controlled heating and cooling of the stem portion of adult Norway spruce over the entire vegetation period 2005 demonstrated that the difference in the number of late phloem cells in treated and control trees was a result of the different time of cessation of cambial activity [10]. As observed in the same study, the rate of production of phloem cells appeared to stay the same, irrespective whether the cambium was cooled, heated or untreated. On the xylem side, temperature had stronger impact on cambial cell production at the very beginning of the growing season, while other factors, not considered in this study, prevailed during late wood formation. On the other hand, the experiments with only short-term heating (before cambial reactivation) and cooling (at the peak of cambial activity) over one month during the growing period of 2004 did not affect the widths and anatomical structure of the phloem increments [27]. Based on the results from these experiments, we can conclude that phloem formation is subjected to smaller fluctuations of environmental conditions that affect seasonal growth than xylem formation. The formation of the phloem growth ring every year is crucial for the long-term survival of a tree. Phloem formation could therefore be particularly endogenously controlled. However, more thorough studies of xylem and phloem formation over a longer period of time are needed to confirm these assumptions.

\section{ACKNOWLEDGMENTS}

We are grateful to our colleagues Peter Cunder and Martin Zupančic for helpful field assistance. We are indebted to the Farmland and Forest Foundation of the 
Republic Slovenia, the Slovenian Forest Service, GGO Bled, and GE Pokljuka and Tomaž Oblak for providing access to the experimental sites.

The work was funded by the Slovenian Research Agency, Ministry of Higher Education, Science, and Technology of the Republic of Slovenia.

\section{REFERENCES}

1. Panshin, A.J. and de Zeeuw, C., Textbook of Wood Technology. 4th Edition, New York: McGraw-Hill, 1980.

2. Larson, P.R., The Vascular Cambium, Berlin: SpringerVerlag, 1994.

3. Kozlowsky, T.T. and Pallardy, S.G., Growth Control in Woody Plants, San Diego: Academic, 1997.

4. Plomion, C., Leprovost, G., and Stokes, A., Wood Formation in Trees, Plant Physiol., 2001, vol. 127, pp. 1513-1523.

5. Antonova, G.F., and Stasova, V.V., Effects of Environmental Factors on Wood Formation in Larch (Larix deciduas Ldb.) Stems, Trees, 1997, vol. 11, pp. 462-468.

6. Horaček, P., Slezingerova, J., and Gandelova, L., Effects of Environment on the Xylogenesis of Norway Spruce (Picea abies ([L.] Karst.), Tree-Ring Analysis. Biological, Methodological and Environmental Aspects, Wimmer, R., and Vetter, R.E., Eds., Oxon: CABI, 1999, pp. 33-54.

7. Deslauriers, A., Dynamique de la croissance radiale et influence météorologique quotidienne chez le sapin baumier (Abies balsamea (L.) Mill.) en forêt boréale, $P h$. D. Dissertation, Chicoutimi: Universite du Quebec a Chicoutimi, 2003.

8. Deslauriers, A. and Morin, H., Intra-Annual Tracheid Production in Balsam Fir Stems and the Effect of Meteorological Variables, Trees, 2005, vol. 19, pp. 402-408.

9. Schmitt, U., Jalkanen, R., and Eckstein, D., Cambium Dynamics of Pinus sylvestris and Betula spp. in the Northern Boreal Forest in Finland. Silva Fenn., 2004, vol. 38, pp. 167-178.

10. Gričar, J., Zupančič, M., Čufar, K., and Oven P., Regular Cambial Activity and Xylem and Phloem Formation in Locally Heated and Cooled Stem Portions of Norway Spruce, Wood Sci. Technol., 2007, vol. 41, pp. 463-475.

11. Rossi, S., Deslauriers, A., Anfodillo, T., Morin, H., Saracino, A., Motta, R., and Borghetti, M., Conifers in Cold Environments Synchronize Maximum Growth Rate of Tree-Ring Formation with Day Length, New Phytol., 2006, vol. 170, pp. 301-310.

12. Alfieri, F.J. and Evert, R.F., Seasonal Development of the Secondary Phloem in Pinus, Am. J. Bot., 1968, vol. 55, pp. 518-528.

RUSSIAN JOURNAL OF PLANT PHYSIOLOGY Vol. 55
13. Alfieri, F.J. and Evert, R.F., Structure and Seasonal Development of the Secondary Phloem in the Pinaceae, Bot. Gaz. (Chicago), 1973, vol. 134, pp. 17-25.

14. Golinowski, W.O., The Anatomical Structure of the Common Fir (Abies alba Mill.) Bark: 1. Development of Bark Tissues, Acta Soc. Bot. Polon., 1971, vol. 40, pp. 149-181.

15. Antonova, G.F. and Stasova, V.V., Seasonal Development of Phloem in Scots Pine Stems, Russ. J. Developm. Biol., 2006, vol. 37, pp. 306-320.

16. Abbe, L.B. and Crafts A.S., Phloem of White Pine and Other Coniferous Species, Bot. Gaz. (Chicago), 1939, vol. 100, pp. 695-722

17. Esau, K., Development and Structure of the Phloem Tissue, Bot. Rev., 1939, vol. 5, pp. 373-432.

18. Holdheide, W., Anatomie mitteleuropaischer Geholzrinden (mit mikrophotographischem Atlas), Handbuch der Mikroskopie in der Technik, Freund, H., Ed., Frankfurt am Main: Umschau-Verlag, 1951, pp. 193-365.

19. Srivastava, L.M., Secondary Phloem in the Pinaceae. University of California Publications in Botany, 1963, vol. 36, pp. 1-42.

20. Srivastava, L.M., Anatomy, Chemistry and Physiology of Bark, Int. Rev. Forestry Res., 1964, vol. 1, pp. 204277.

21. Srivastava, L.M. and O'Brian, T.P., On the Ultrastructure of Cambium and Its Vascular Derivatives, Protoplasma, 1966, vol. 61, pp. 277-293.

22. Trockenbrodt, M., Survey and Discussion of the Terminology used in Bark Anatomy, IAWA Bulletin n.s., 1990, vol. 11, pp. 141-166.

23. Kutscha, N.P., Hyland, F., and Schwarzmann, J.M., Certain Seasonal Changes in Balsam Fir Cambium and Its Derivatives, Wood Sci. Technol., 1975, vol. 9, pp. 175188.

24. Schweingruber, F.H., Tree Rings and Environment: Dendroecology, Bern: Swiss Federal Institute for Forest, Snow and Landscape Research and Paul Haupt Verlag, 1996.

25. Gričar, J., Effect of Temperature and Precipitation on Xylogenesis of Silver Fir (Abies alba) and Norway Spruce (Picea abies), Ph. D. Dissertation, Ljubljana: University of Ljubljana, 2006.

26. Dobbertin M., Tree Growth as Indicator of Tree Vitality and Tree Reaction to Environmental Stress: A Review, Eur. J. Forest Res., 2005, vol. 124, pp. 319-333.

27. Gričar, J., Zupančič, M., Čufar, K., Koch, G., Schmitt, U., and Oven, P., Effect of Local Heating and Cooling on Cambial Activity and Cell Differentiation in Stem of Norway Spruce, Ann. Bot., 2006, vol. 97, pp. 943-951.

No. 42008 